\title{
ДОСВІД ОРГАНІЗАЦІЇ НАВЧАННЯ В ІНТЕРНАТУРІ
}

\author{
М. В. Гребеник, Т. Б. Лазарчук, О. І. Криськів \\ ДВНЗ “Тернопільський державний медичний університет \\ імені І. Я. Горбачевського МОЗ України”
}

\section{EXPERIENCE OF ORGANIZATION OF STUDIES IN INTERNSHIP}

\author{
M. V. Hrebenyk, T. B. Lazarchuk, O. I. Kryskiv \\ I. Horbachevsky Ternopil State Medical University
}

\begin{abstract}
Підготовка компетентного спеціаліста, здатного забезпечити належний рівень медичної допомоги в умовах інформаційних потоків та сучасних технологій, вимагає переорієнтації системи післядипломної освіти на індивідуальне навчання майбутнього спеціаліста у супроводі викладача. У статті висвітлено багаторічний досвід кафедри терапії і сімейної медицини навчально-наукового інституту ТДМУ із використання методології адаптації набутих на додипломному етапі знань та умінь молодих лікарів до роботи в реальних умовах практичної медицини.
\end{abstract}

Training of a competent specialist able to provide the appropriate level of care in terms of information flows and modern technology requires a determination of postgraduate education system on the individual training of future specialists, accompanied by a teacher. Long experience of therapy and family medicine research institute of TSMU of usage at the graduation stage acquired knowledge and skills adapt methodologies of young doctors for training in the real practical medicine is described in this article.

Вступ. Переорієнтація вітчизняної системи охорони здоров'я на профілактичну та превентивну медицину лягла в основу реформування галузі в Україні з акцентом на первинній ланці надання медичної допомоги. Зміна вимог до лікаря налаштовує освітян на підготовку спеціаліста із високою професійною компетенцією, здатного забезпечити належний рівень медичної допомоги в умовах надшвидких потоків інформації та сучасних технологій. Якість підготовки спеціаліста залежить від багатьох факторів. 3 одного боку, це професіоналізм викладачів, умови та забезпеченість навчального процесу, сучасні освітні та контролюючі технології, з іншого - готовність інтерна сприйняти, переосмислити та використати у своїй роботі усю багатогранність лікарського мистецтва. Отже, розкриття творчого потенціалу кожного інтерна $€$ неодмінною складовою якості навчання. Вирішення цього завдання вимагає впровадження нових форм раціональної організації навчального процесу із переважанням методів, що сприяють формуванню активного, усвідомленого і безперервного набуття професійних знань та вмінь на післядипломному рівні [3].

(c) М. В. Гребеник, Т. Б. Лазарчук, О. І. Криськів
Основна частина. Європейське бачення надання сучасної якісної медичної допомоги полягає у постійному підтриманні компетентності лікарів шляхом участі в програмах безперервного підвищення та оцінки своєї кваліфікації. Саме тому у Європі актуальними є програми безперервного професійного розвитку як академічного, так і індивідуального [1]. Головним вектором розвитку у цьому напрямку слід вважати індивідуалізацію освітнього процесу та розвиток нових форм взаємодії викладача та слухача в процесі навчання. Відповідно до цього необхідним $є$ вивчення принципів оцінювання запитів інтернів про необхідний їм основний та додатковий навчальний матеріал. Це можна проводити, аналізуючи статистику звернень інтернів до навчальних матеріалів єдиного інформаційно-освітнього простору та зіставлення обсягу навчальних програм з потребами ринку [2].

Обов'язковими умовами продуктивного навчання на післядипломному етапі є усвідомлення сутності професії, якої навчаєшся, своїх професійних якостей та їх відповідності ідеалам у власному розумінні, професійних прагнень та строків їх реалізації. Якщо навчання на додипломному етапі здатне сформувати уявлення про сутність медичної діяльності та ідеали лікарського мистецтва, то розуміння 
власних здібностей та прагнень формується під час самостійної роботи. Навчаючись в інтернатурі, молоді лікарі повинні усвідомити для себе чого вони прагнуть від навчання та в удосконаленні яких навичок потребують підтримки. На нашу думку, вже у самому утвердженні лікаря як професіонала як основу закладено потребу у самонавчанні та самовдосконаленні за допомоги та настанови викладача.

Для оцінки ступеня усвідомлення інтернами мети та цілей навчання ми провели анонімне опитування. Опитувальник включав п’ять запитань, не містив шаблонів відповідей, а отже, вимагав від респондента замислитися та викласти свої власні міркування щодо розуміння поняття успішного лікаря, усвідомлення професійної самоідентифікації, термінів досягнення поставлених цілей, а також щодо очікувань від навчання в інтернатурі та фахової допомоги викладачів.

Аналіз анкет продемонстрував, що для більшості лікарів (88,8 \%) “успішний лікар” - це професійний, компетентний з основних питань медицини лікар, здатний надати адекватну планову та невідкладну допомогу (18,8 \%), спроможний утримувати себе та родину (38,5 \%), для решти 12,2 \% “успішний лікар” - це лікар, глибоко обізнаний у певній галузі медицини, з високим рівнем життя. При цьому кардіологію як пріоритетний напрямок вивчення розглядають 27,7 \%; ендокринологію та гастроентерологію - теж 27,7 \%; майбутніми викладачами та посадовцями себе вбачають 22,2 \% опитаних, а 22,4 \% налаштовані на роботу терапевтом. Цікаво, що про доцільність ознайомлення 3 правовими аспектами лікарської діяльності заявили тільки 2 респонденти, а про допомогу у питаннях збереження здоров’я та попередження розвитку захворювання не висловився жоден з опитуваних.

Щодо строків досягнення професійного рівня, то 72,2 \% впевнено почувати себе у професії збираються вже через $(3,87 \pm 0,12)$ року, а 27,8 \% для досягнення своїх цілей відводять термін у $(8,81 \pm 1,24)$ року. Про необхідність постійного активного самовдосконалення висловилися 38,9 \%. Проте ми розуміємо, що це не свідчить про заперечення іншими цієї необхідності, лише - про неважливість.

На запитання щодо очікувань від інтернатури більшість лікарів (77,8 \%) усвідомлює основну задачу підготовки в інтернатурі як набуття практичного досвіду шляхом синтезу теоретичних знань та практичних умінь, що, власне, і відповідає завданням підготовки лікаря-інтерна, визначених у типовому навчальному плані і програмі МОЗ України з фаху “Внутрішні хвороби”. При цьому навчання в інтернатурі як хорошу можливість набути практичного досвіду та впевненості у своїх силах розглядають 50 \% лікарів-інтернів, частина 3 яких відчуває потребу в удосконаленні комунікативних здібностей (22,2 \%).

Таким чином, випускники вищих медичних закладів, які розпочали навчання в інтернатурі, у своїй більшості усвідомлюють його важливість для надбання практичного досвіду. При цьому частина з них уявляє, в якому напрямку медичної діяльності хочуть реалізувати набуті знання та уміння, розуміючи важливість матеріальної складової (що не заперечує вибір за покликанням), проте не визначаючи за важливі (на даному етапі) правові аспекти лікарської діяльності та не усвідомлюючи важливість превентивної медицини.

За нашими багаторічними спостереженнями, далеко не кожний інтерн, володіючи певною сумою теоретичних знань (іноді фундаментальних), здатний реалізувати їх у реальних умовах лікарської роботи в силу недостатності комунікативних та спеціальних практичних умінь. Тому основну свою задачу ми вбачаємо у формуванні цілісного статусу лікаря шляхом формування системного клінічного мислення як основи лікарської майстерності, відпрацювання практичних умінь та ефективних комунікацій.

У робочих програмах левова частка навчального часу (70 \%) відводиться на практичну роботу у базових підрозділах кафедри в режимі реального часу. Самостійна робота інтерна із пацієнтами спрямовується і контролюється безпосередньо викладачем. На початкових етапах навчання особлива увага приділяється відпрацюванню навичок особистісноорієнтованого підходу до пацієнта, умінню професійно обстежити хворого. Розвиток кваліфікаційної компетенції та особистісно-орієнтованої взаємодії передбачає формування стилю спілкування з пацієнтом, спрямований на досягнення партнерства при призначенні діагностично-лікувальної програми. Принцип “дивись-слухай-запам’ ятовуй”, який реалізується під час пасивної участі інтернів у клінічних обходах, консультативних та амбулаторних прийомах викладачів, лікарів-ординаторів, згодом трансформується у принцип “думай-роби”, який реалізується під час активної самостійної роботи інтерна з пацієнтом, участі в обходах у якості доповідача 3 наступним обов’язковим аналізом послідовності, доцільності, компетентності дій лікаря-інтерна та окресленням питань, що вимагають удосконалення. 
Інтерн повинен усвідомити, що індивідуалізований підхід до пацієнта дозволяє вже під час збору анамнестичних даних виділяти і вирішувати певні проблеми хворого, приймати правильне рішення у невідкладних ситуаціях. Запитання до себе на кшталт “що ще?”, “які можуть бути наслідки для тебе та інших?”, “якими критеріями ти користуєшся ?”, “що б ти порадив іншому, будь він на твоєму місці?”, “чия підтримка тобі потрібна?” тощо повинні супроводжувати лікарську діяльність. Оволодіння методологією обстеження, визначення раціонального діагностичного пошуку на недиференційованих стадіях захворювання, формування лікувальної тактики з дотриманням вимог діючих в Україні регламентуючих документів є складовою професійної компетенції, однією з вимог до компетенції майбутнього спеціаліста і тому перебувають у центрі уваги викладача. Завершується практична частина розбором конкретного клінічного випадку, який обирає сам інтерн, керуючись запитаннями, що виникли у нього під час роботи з хворим. При цьому вся група бере участь за попередньо розподіленими ролями - лікуючий лікар, консультант, завідувач відділення тощо, намагаючись відповісти на запитання, вирішуючи тактику і стратегію ведення хворого.

Чергування, запроваджені у нашій клініці, розширюють можливості професійного удосконалення інтерна, є своєрідною перевіркою готовності до самостійної роботи. Результати чергування доповідають на щоденних ранкових конференціях, 3 обов’язковим розбором клінічної ситуації, що становить труднощі у діагностичному, лікувальному, тактичному, організаційному плані. Доповіді про рідкісні хвороби та стани обов'язково супроводжуються тематичними презентаціями. При цьому оцінюється не тільки об'єм роботи, виконаний під час чергування, а й уміння доповісти ситуацію, виділити коло проблем, що виникли, та шляхи їх вирішення. Добре підготовленими вважають ті доповіді, що відстежують розвиток клінічної ситуації і містять їх ретроспективний аналіз, а також обговорення допущених у діагностичному та лікувальному процесі помилок.

Відпрацювання стандартів надання медичної допомоги відбувається і під час інтерактивних лекцій із зворотним зв'язком між суб'єктами процесу, що вимагає підготовки і від інтерна. Матеріали підготовки до лекційних занять розміщені на сайті університету і доступні для вивчення. Проте особливо цінується обгрунтовано критичне сприйняття інформації, що базується на власному досвіді. Такі лекції, як правило, краще сприймаються інтернами другого року навчання, тоді як інтерни-початківці долучаються до активної участі лектором.

Для кращого запам’ятовування та систематизації практичного досвіду інтернам рекомендується створювати “портфоліо” - записи про клінічні випадки у практиці, патологоанатомічні конференції, відвідування додаткових освітніх заходів різних рівнів (семінари, симпозіуми, конференції, школи професійної майстерності) з особистою оцінкою їх цінності тощо. Крім того, вже на початку навчання інтернам пропонується самостійно обрати тему науково-практичної роботи (що також є складовою навчальної програми), яка передбачає огляд літературних джерел з дискусійних медичних питань, що ілюструється власними клінічними спостереженнями. Наприкінці навчання в інтернатурі результати робіт обговорюються в групах, а визначені викладачем та колегами як кращі - виносяться на заключну науково-практичну конференцію. Автор роботи-переможця може бути рекомендований для подальшого навчання у клінічній ординатурі.

У формуванні лікарського стереотипу неможливо недооцінити користь роботи в умовах навчальнопрактичних центрів (НПЦ), створених на базі первинних медико-санітарних центрів, розташованих у селах нашої області. Саме в умовах самостійного прийняття рішення інтерн може відчути свої “слабкі місця”, відпрацювати техніку спілкування з пацієнтами, середнім медичним персоналом, удосконалити техніку лікарських маніпуляцій (наприклад: запис та розшифровка ЕКГ, використання небулайзера для лікування бронхообструкційних станів, проведення внутрішньовенних маніпуляцій, накладання пов'язок тощо), надавати невідкладну допомогу. Інтерни мають можливість у складних ситуаціях скористатися консультативною допомогою викладачів університету через Internet, що дозволяє, з одного боку, відчути себе захищеним, з іншого - уникнути небажаних наслідків некоректних рішень. Безумовним позитивом $€$ і безпосередня робота з первинною документацією, якість заповнення якої контролюється викладачем. Інтерни набувають практичного досвіду епідеміологічної роботи, аналізуючи поширеність тих чи інших нозологій у конкретній місцевості із спробою встановлення причинно-наслідкових зв'язків. Участь у консультативному прийомі викладача (відбір хворих на консультацію до спеціаліста здійснює інтерн впродовж тижня) дозволяє знайти відповіді 
на неясні питання та усвідомити недоліки, допущені у курації пацієнта. Позитивна оцінка інтернами досвіду самостійної роботи у НПЦ та посилення зацікавленості у клінічній роботі засвідчують доцільність розвитку цього навчального напрямку.

Висновок. Таким чином, залучення інтернів до активної участі у діагностично-лікувальному процесі з постійним аналізуванням викладачем пра-

\section{Список літератури}

1. Тенденції інтеграції систем підготовки та атестації медичних кадрів у світі та Україні / Ю. В. Вороненко, Ю. П. Вдовиченко, О. К Толстанов [та ін.] // Медична освіта. - 2015. - № 2. - С. 41-45.

2. Вороненко Ю. В. Єдиний медичний (фармацевтичний) освітній простір - стратегія, регіональні та локаль- вильності їхніх дій, акцентуванням уваги на проблемах спілкування, сприйняття та використання отриманої інформації, дотримання протоколів надання медичної допомоги, вибору алгоритму ведення пацієнта залежно від клінічної ситуації, а також стимулювання пізнавальної діяльності сприяють формуванню “правильного” поведінкового стереотипу лікаря-початківця - відправної точки успішного професійного життя.

ні рішення / Ю. В. Вороненко, О. П. Мінцер // Медична освіта. - 2015. - № 2. - С. 86-88.

3. Инновационные методы оптимизации учебного процесса в вузе / С. М. Саркулова, И. А. Самченко, Г. Н. Досыбаева [и др.] // Вестник ЮКГМА. - 2005. № 5. - С. 143-147. 